\title{
Non-random Association of Chromosomes during Mitotic Metaphase in Tissue Cells of the Mouse ${ }^{1}$
}

\author{
Dorothea Bennett ${ }^{2}$ \\ Department of Anatomy, Cornell University Medical College, \\ New York City, U.S.A.
}

Received November 18, 1965

\section{Introduction}

It has frequently been pointed out by students of human chromosomes (Ferguson. Smith and Handmaker 1961, 1963, Edwards 1961, Van Brink et al., 1962) that in mitotic cells at metaphase certain chromosomes appear in close spatial association with one another more frequently than would be expected by chance. The chromosomes most conspicuously involved in such associations are those with satellites, although others, especially those known to have minor or variably present secondary constrictions, may also participate in them. It has been considered likely that these constellations of chromosomes reflect their earlier participation, during interphase, in the organization of a nucleolus (Ferguson-Smith 1963).

The purpose of this report is to present evidence of similar associations amongst metaphase chromosomes in tissue cells of the mouse.

\section{Materials and methods}

The colchicine-hypotonic citrate-air drying method of Ford and Woollam (1963) was used for chromosome preparations of liver cells from 14-17 day old mouse embryos. Cells in metaphase whose chromosomes were well extended, essentially non-overlapping, and which showed clearly 6 chromosomes with satellites were selected, photographed, and enlarged to a final magnification on the print of about $4500 \times$. This material was collected originally for a different purpose (Bennett 1965). Therefore, there should be no bias in favor of metaphase plates showing clear associations of chromosomes, but rather the reverse, since one of the criteria for selection for photography was adequate spatial separation of the chromosomes. A total of 89 metaphase plates were analyzed in this study and scanned independently by two observers for the detection of possible non-random associations of chromosomes.

\section{Results}

Identification of associations. Some of the metaphase figures contained apparently non-random associations of chromosomes which struck the eye at once Figs. 1-5. The identification of such associations is thus based subjectively on the striking and unmistakable arrangement of chromosomes in a ring-like pattern with their centromeric ends oriented toward a common point. However, these associations form such discrete and visually definite units, that excellent agreement, almost $100 \%$, was obtained both on successive

1 This work was supported by USPHS grant, GM 9912.

2 Career Scientist, Health Research Council of the City of New York. 
independent evaluations by the same observer, and on identifications made independently by two observers.

The original associations scored were all of three or more chromosomes. It was noted at the same time, however, that there were numerous instances

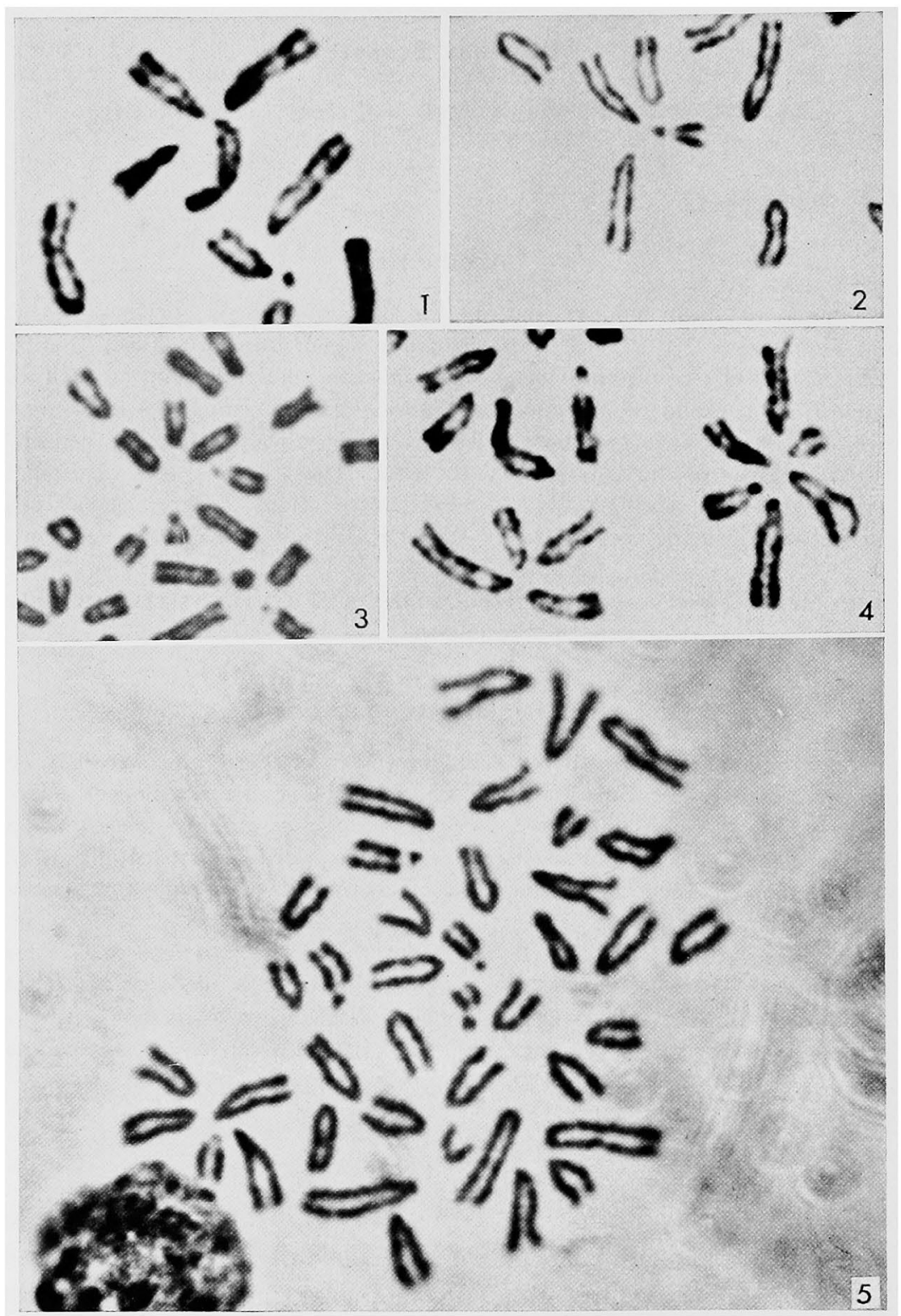

Figs. 1-5

where just two chromosomes lay with their centromeric ends close together. These typically showed an end to end relationship which seemed similar in general orientation to that in the larger associations. It was thought worthwhile to count these possible two-by-two associations as well, and to analyze them for their chromosome constitution. The criteria for accepting two-by-two 
associations were more definite than in the case of group associations. The two chromosomes were required to have their two centromeric ends pointing directly at each other at a distance of not more than 3 or $4 \mathrm{~mm}$ on the photograph, and with an angle between them of greater than 90 degrees.

Table 1. Distribution of satellited and non-satellited chromosomes associated in groups of three or more

\begin{tabular}{l|c|c}
\hline & Observed & $\begin{array}{c}\text { Random } \\
\text { expectation }\end{array}$ \\
\hline Non-satellited & 99 & 113.9 \\
Long-satellited & 8 \\
Medium-satellited & 14 \\
Short-satellited & 13 & 6.7 \\
Total chromosomes & 134 & 6.7 \\
\hline
\end{tabular}

$\mathrm{Chi}^{2}$ based on two groups (satellited vs. non-satellited $=12.9$

$\mathrm{p}<.01$

$\mathrm{Chi}^{2}$ based on 4 groups (as above) $=15.9$

$$
\mathrm{p}<.01
$$

Associations of three or more chromosomes. In the 89 metaphase figures examined, 25 associations of three or more chromosomes were detected. A representative sample of these configurations is given in Figs. 1-5. Fourteen of them contained at least one chromosome with a satellite, 11 had none. The question at issue was whether the chromosomes involved in these associations represented a random sample of the total chromosome population, or whether certain of them, e.g. those with satellites, were more heavily represented than the others.

As was indicated previously, three presumed pairs of chromosomes with satellites could be detected in these cells, and each of these pairs could be distinguished from the others by size, and classified as long, medium, or short (Bennett 1965). Table 1 gives the distribution of these three pairs found in the associations and compares it with the number expected if there were random assortment. Clearly, the chromosomes with satellites participate in associations much more frequently than expected by chance, and this is particularly true of those of medium and short length.

Association by twos. In the same material, 92 cases of association by twos were found; 48 between two non-satellited chromosomes, 40 with one satellited chromosome, and 4 between two satellited chromosomes. Table 2 gives these data in detail, and indicates that the participation of chromosomes with satellites in two-by-two associations again far exceeds the expectation on the basis of chance.

\section{Discussion}

The observations presented here seem to indicate quite clearly that meta- 
phase chromosomes in air dried preparations of mouse tissue cells frequently are found in configurations which are spatially non-random, and that chromosomes with satellites are found in such associations in far greater proportion than expected by random assortment. This supports the idea that these as-

Table 2. The distribution of satellited and non-satellited chromosomes associated by twos

\begin{tabular}{|c|c|c|}
\hline & $\begin{array}{l}\text { \# "pairs" } \\
\text { observed }\end{array}$ & $\begin{array}{l}\text { \# “pairs" expected } \\
\text { randomly }\end{array}$ \\
\hline Non-satellited $\times$ Non-satellited & 43 & 66.5 \\
\hline$\times$ Long-satellited & $17)$ & $7.8)$ \\
\hline$\times$ Medium satellited & 1140 & $7.8\} 23.4$ \\
\hline " $\times$ Short-satellited & $12)$ & $7.8)$ \\
\hline Long-satellited $\times$ Long-satellited & 0 & 0.2 \\
\hline$\times$ Medium-satellited & 1 & 0.5 \\
\hline Medium-satellited $\times$ Medium-satellited & $3\} 4$ & $0.2\} 1.6$ \\
\hline " $\quad \times$ Short-satellited & 0 & 0.5 \\
\hline Short-satellited $\times$ Short-satellited & 01 & 0.21 \\
\hline Total & 92 & 91.5 \\
\hline
\end{tabular}

$\mathrm{Chi}^{2}$ based on: non-satellited $\times$ non-satellited non-satellited $\times$ satellited satellited $\times$ satellited

$$
\begin{aligned}
& =20.1 \\
p & <.01
\end{aligned}
$$

sociations might reflect previous engagement in nucleolar organization, since chromosomes with secondary constrictions, in this case chromosomes with satellites, are thought to be responsible for the organization of a nucleolus. However, the presence of a chromosome with a satellite is not a necessary prerequisite for association, since about half of the total number of groups or pairs detected contained only non-satellited chromosomes. The question thus arises whether all the associations found in this survey can in fact be considered to represent a former common involvement in the organization of a nucleolus during the previous interphase. If they do, it must be assumed that chromosomes with satellites are not always involved in that organization. On the other hand it is of course quite possible that some of the associations are fortuitous and without functional significance, or that they may reflect some other and unknown functional relationship unrelated to nucleolar organization.

\section{Abstract}

Examination of air dried preparations of metaphase figures in mouse embryonic liver cells in which three pairs of chromosomes with satellites can be demonstrated shows clearly ring-like and end to end associations of chromosomes which appear to be spatially non-random. The chromosomes with satellites participate in these associations much more frequently than 
expected by chance. The possible significance of these associations in terms of nucleolus organization is discussed.

\section{Acknowledgments}

I am grateful to Fay Shutsky for painstaking work in independent evaluation of this material.

\section{References}

Bennett, D. 1965. The karyotype of the mouse, with identification of a translocation. Proc. Nat. Acad. Sci. 53: 730-370.

Edwards, J. H. 1961. Chromosome association in man. Lancet 2: 317.

Ferguson-Smith, M. A. and Handmaker, S. D. 1961. Observations on the satellited human chromosomes. Lancet 1: 638-640.

- and - 1963. The association of satellited chromosomes with specific chromosomal regions in cultured human somatic cells. Ann. Hum. Genet. 27: 143-156.

Ford, E. H. R., and Woollam, D. H. M. 1963. A colchicine, hypotonic citrate, air drying sequence for foetal mammalian chromosomes. Stain Tech. 38: 271-274.

Van Brink, J. M., Los, P. L. and Nienhaus, A. J. 1962. Satellite associations and the identi. fication of the $\mathrm{Y}$ chromosome in man. Genetics 23: 45-51. 